\title{
Anaerobic methane oxidation in sulfate depleted sediments: effects of sulfate and molybdate additions
}

\author{
Lars Bille Hansen $^{1, * *}$, Kai Finster ${ }^{1, *}$, Henrik Fossing ${ }^{1, * * *}$, Niels Iversen ${ }^{2}$ \\ ${ }^{1}$ Department of Microbial Ecology, Institute of Biological Sciences, University of Aarhus, Ny Munkegade, Building 540, \\ DK-8000 Aarhus C, Denmark \\ ${ }^{2}$ Environmental Engineering Laboratory, Aalborg University, Sohngaardsholmsvej 57, DK-9000 Aalborg, Denmark
}

\begin{abstract}
Anaerobic methane oxidation and sulfate reduction were investigated in intact marine sediment cores and in headspace-free, undiluted, homogenized, incubation bags. In intact cores, the typical upward concave methane concentration profile indicated methane oxidation in the anoxic part of the sediment. Generally, sulfate reduction rates exceeded methane oxidation rates many-fold, except in one case, where methane oxidation exceeded sulfate reduction 2 to 8 times. In the sulfatemethane transition zone, sulfate reduction was stimulated compared to rates measured above and below. Methane oxidation rates determined in incubation bags were equivalent to rates determined in intact sediment cores. Methane oxidation rates were proportional to the concentrations of methane and also increased with increasing methane concentrations in the absence of sulfate or the presence of molybdate. When sulfate was added to sulfate-depleted incubation bags, methane oxidation rates decreased immediately to less than half the rate measured prior to the addition, while sulfate reduction was stimulated. When molybdate (a specific inhibitor of sulfate-reducing bacteria) was added to a sulfate-free incubation bag, methane oxidation responded after a lag period of approximately $3 \mathrm{~d}$, by uncoupling methane oxidation rates from methane concentrations. Methane production was not affected. From the outcome of our incubation bag experiments we conclude that methane is not, as previously proposed, oxidized by sulfate reducers alone. Our results support the hypothesis of Hoehler et al. (1994; Global Biogeochem Cycles 8:451-463), who proposed that a consortium of methanogenic bacteria and sulfate reducers is responsible for net oxidation of methane under anoxic conditions, a process called 'reverse methanogenesis'
\end{abstract}

KEY WORDS: Anaerobic methane oxidation - Marine sediment - Incubation bag - Sulfate reduction · Reverse methanogenesis

\section{INTRODUCTION}

Methane produced in anoxic marine sediments rarely escapes into the oxic environment because it is oxidized as it diffuses upward through sulfate-rich but

\footnotetext{
-Addressee for correspondence. E-mail: kai@bio.aau.dk Present addresses:

- County of North Jutland, Dept. for Environmental and Technical Affairs, Niels Bohrsvej 30, DK-9220 Aalborg, Denmark

-. National Environmental Research Institute, Department of Lake and Estuarine Ecology, Vejlsøvej 25, PO Box 314, DK-8600 Silkeborg, Denmark
}

reduced sediment (Reeburgh 1976, Martens \& Berner 1977, Iversen \& Jørgensen 1985). From results of ${ }^{14} \mathrm{C}$ methane tracer experiments (Reeburgh 1980, Iversen \& Blackburn 1981) and from methane and carbon dioxide stable carbon isotope ratios (Blair \& Aller 1995, Popp et al. 1995) it has been concluded that methane oxidation in anoxic environments is microbially mediated. Further, anaerobic oxidation of methane is considered an important factor decreasing the flux of methane from marine sediments. However, the oxidation mechanism is still unknown. Several authors (Martens \& Berner 1977, Iversen \& Blackburn 1981, Devol 1983, Devol et al. 1984, Alperin \& Reeburgh 
1985, Iversen \& Jørgensen 1985, Hoehler et al, 1994) have argued that anaerobic methane oxidation is most probably linked directly or indirectly to sulfate reduction. Martens \& Berner (1977) calculated that methane oxidation through sulfate reduction is thermodynamically favourable $\left(\Delta \mathrm{G}^{\circ}=-25.1 \mathrm{~kJ}\right)$ at in situ concentrations:

$$
\mathrm{CH}_{4}+\mathrm{SO}_{4}{ }^{2-}+2 \mathrm{H}^{+} \rightarrow \mathrm{CO}_{2}+\mathrm{H}_{2} \mathrm{~S}+2 \mathrm{H}_{2} \mathrm{O}
$$

The hypothesis of a direct or indirect coupling between methane oxidation and sulfate reduction is further strengthened by observations of coinciding maximum rates of methane oxidation and sulfate reduction in the narrow transition zone between sulfate and methane (Devol 1983, Devol et al. 1984 Alperin \& Reeburgh 1985, Iversen \& Jørgensen 1985). In Danish coastal sediments (Kattegat and Skagerrak) for example, the methane oxidation could account for more than $60 \%$ of sulfate reduction in the methane oxidation zone, assuming a coupling between the 2 processes (Iversen \& Jørgensen 1985). However, no in situ observations have confirmed a direct coupling between methane oxidation and sulfate reduction.

Recently, Hoehler et al. (1994) proposed that methane is oxidized by a consortium of methanogenic and sulfate-reducing bacteria. According to their hypothesis, the first step in methane oxidation is the production of carbon dioxide and hydrogen through 'reverse methanogenesis':

$$
\mathrm{CH}_{4}+2 \mathrm{H}_{2} \mathrm{O} \rightarrow \mathrm{CO}_{2}+4 \mathrm{H}_{2}
$$

followed by the oxidation of $\mathrm{H}_{2}$ by sulfate-reducing bacteria:

$$
\mathrm{SO}_{4}{ }^{2-}+4 \mathrm{H}_{2}+2 \mathrm{H}^{+} \rightarrow \mathrm{H}_{2} \mathrm{~S}+4 \mathrm{H}_{2} \mathrm{O}
$$

Thus, the overall reaction of this 2 -step methane oxidation pathway equals the reaction shown in Eq. (1). From thermodynamic calculations, it was concluded that 'reverse methanogenesis' is only energetically favourable at $\mathrm{H}_{2}$ concentration $<0.29 \mathrm{nM}$. Consequently, an interaction with hydrogen-scrubbing organisms is necessary, which led the authors to propose a dependence on sulfate-reducing bacteria.

Zehnder \& Brock (1980) proposed that anaerobic methane oxidation could be explained by a bacterial consortium consisting of at least 2 groups of organisms, with sulfate-reducing bacteria as one possible member. They speculated on acetate or methanol as possible intermediates, which were accordingly transferred from one group to the other. Even though sulfate reducers often have been mentioned in the context of anaerobic methane oxidation, only a few species have been tested for this property. For example, Desulfovibrio desulfuricans co-oxidizes methane in the presence of another electron donor, e.g. pyruvate (Davis \&
Yarborough 1966), but is unable to grow on methane alone (Sorokin 1957, Postgate 1969). Iversen (1984) calculated that $0.3 \%$ of the sulfate reduction in pure cultures of 3 Desulfovibrio strains grown in the presence of pyruvate and methane could be accounted for by methane oxidation. Harder (1997), testing sulfate reducers utilizing the acetyl-CoA/carbon monoxidedehydrogenase pathway, showed that none of the organisms was able to oxidize ${ }^{14} \mathrm{C}$-methane. In addition, he confirmed the results obtained by Zehnder \& Brock (1979), saying that methanogens reoxidize part of the methane formed during methanogenesis. Recently, and for the first time, sulfate-reducing bacteria able to grow from the oxidation of long-chain saturated hydrocarbons to $\mathrm{CO}_{2}$ have successfully been isolated by Aeckersberg et al. (1991). However, these sulfate-reducing bacteria were unable to grow on methane.

In this paper we present and discuss results from methane oxidation experiments performed under anoxic conditions in both undisturbed sediment cores and in gas-tight incubation bags. We made use of a recently introduced bag incubation system (Hansen 1992, Kruse 1993) that allows long-term anoxic incubations with non-diluted homogenized sediment without introducing a gas phase. Sulfate-depleted sediment was amended with sulfate or molybdate to stimulate or completely inhibit sulfate reduction and to study the relation between methane oxidation and sulfate reduction under anoxic conditions

\section{MATERIAL AND METHODS}

Sediment samples were collected during summer 1992 from Norsminde Fjord, a shallow inlet on the east coast of Jutland, Denmark. The salinity of the water varied between 7 and $22 \%$ according to freshwater inputs and exchange of sea water. The sediment consisted of fine-grained sand and silt rich in organic matter ( 6 to $22 \%$ dry weight). The sediment was permanently reduced beneath the top 3 or $4 \mathrm{~mm}$. No living macrofauna were observed in the reduced part of the sediment.

Sediment sampling and handling. At each sampling five $50 \mathrm{~cm}$ long cores $(8 \mathrm{~cm}$ outer diameter, OD) were collected in close proximity to each other by gently pushing $1 \mathrm{~m}$ PVC tubes into the sediment. The core liners were capped and immediately returned to the laboratory where they were stored at in situ temperature $\left(15\right.$ to $\left.20^{\circ} \mathrm{C}\right)$ and handled within $24 \mathrm{~h}$ after sampling. From 1 sediment core, methane and sulfate concentrations were determined at $5 \mathrm{~cm}$ (or narrower) intervals together with rate measurements of methane oxidation and sulfate reduction. Before subsampling, the PVC 
tube was extended by a $10 \mathrm{~cm}$ long core liner with a $15 \mathrm{~mm}$ port hole in the side. The sediment was then pushed gently into the 'extension core liner' and subsamples were withdrawn horizontally through the port hole into an incubation syringe (described below). In addition to these measurements, porosity, chlorinity and organic matter were also determined. Of the remaining 4 sediment cores only the sediment from the sulfate-methane transition zone was used for further studies.

Bag incubation experiments: Sediment used for bag incubation experiments was collected on August 2, 1992. Sediment from around the sulfate-methane transition zone (defined as the depth interval where the concentration of methane increased abruptly and sulfate was present at $<3$ and $>0.1 \mathrm{mM}$ ) were sectioned into 3 depth intervals: (1) an approximately $6 \mathrm{~cm}$ thick section immediately above the sulfate-methane transition zone. In this section, methane concentration was generally $<100 \mathrm{nmol} \mathrm{cm}^{-3}$ and sulfate concentration was > $3 \mathrm{mM}$; (2) the $6 \mathrm{~cm}$ thick sulfate-methane transition zone; here methane concentration was between

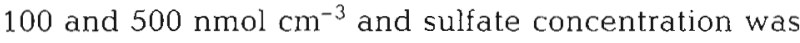
$>0.1 \mathrm{mM}_{i}$ (3) an approximately $6 \mathrm{~cm}$ thick section immediately below the sulfate-methane transition zone; here the methane concentration was $>500 \mathrm{nmol}$ $\mathrm{cm}^{-3}$ and sulfate was not detectable (i.e. $<0.01 \mathrm{mM}$ ).

Approximately $300 \mathrm{~cm}^{3}$ of homogenized sediment from each depth interval was put into a gas-tight plastic bag. The plastic material was made of 4 layers: $40 \mu \mathrm{m}$ nylon (outside), $6.5 \mu \mathrm{m}$ methylene-vinyl-alcohol, $40 \mu \mathrm{m}$ nylon and $100 \mu \mathrm{m}$ polyethylene (inside) (Otto Nielsen Emballage, 2800 Lyngby, Denmark). Three bags were filled with sediment from each depth interval and immediately sealed. One bag served as control whereas the other 2 bags were used for sulfate and molybdate additions, respectively. Each bag was supplied with a rubber-stoppered glass tube for subsampling and for addition of sulfate or molybdate. To avoid contamination with oxygen all bag incubations and sediment handling were performed in a glove bag (Coy) with an atmosphere of $95 \%$ nitrogen and $5 \%$ hydrogen securing an $\mathrm{O}_{2}$ concentration below 1 ppm.

Sediment was subsampled from the 3 incubation bags approximately every other day for almost 1 mo. During this period, the bags were also manipulated by additions of sulfate, molybdate or water as described below. After each subsampling, concentrations of sulfate and methane were determined together with the rates of sulfate reduction and methane oxidation.

Control experiments: Anoxic Milli-Q water instead of a similar volume of a sulfate or molybdate solution was added to the control bag from each depth interval. The addition was made at the same time as sulfate and molybdate were added to the other bags. The addition of the Milli- $Q$ water did not change the water content of the sediment significantly ( $<0.2 \%$ increase in volume).

Sulfate-amended experiments: Sulfale was added to the second bag from each depth interval after the original sulfate pool was depleted through sulfate reduction, and the methane concentration equalled the maximum $\mathrm{CH}_{4}$ concentration measured in the undisturbed core. Sulfate was added to a final concentration of approximately $2 \mu \mathrm{mol} \mathrm{cm}^{-3}$ (i.e. in situ $\mathrm{SO}_{4}{ }^{2-}$ concentration in the sulfate-methane transition zone). The incubation bag was thoroughly kneaded ( 4 to $5 \mathrm{~min}$ ) until the sulfate was evenly distributed in the sediment.

Molybdate inhibition experiments: Molybdate was added to the third bag at the same time as sulfate or water were added to the other bags. Molybdate was also added to the sulfate-amended bag ( 6 to 9 d after sulfate addition) in order to control the inhibition on sulfate reduction. The final concentration of molybdate was 1 to $2.5 \mu \mathrm{mol} \mathrm{cm}^{-3}$, and equalled the sulfate concentration in the sulfate amended experiments.

Analyses. Sulfate: Sulfate concentrations were measured in porewater collected from sediment after pressure filtration through a $0.45 \mu \mathrm{m}$ membrane filter; porewater was preserved in $0.5 \mathrm{ml}, 1.6 \%$ zinc acetate $(\mathrm{w} / \mathrm{v})$ (whole cores) or $0.5 \mathrm{ml}, 0.5 \% \mathrm{ZnCl}_{2}$ (bag incubations). Zinc acetate ( $\mathrm{ZnAc}$ ) was used to allow chlorinity determination in the sediment cores. Filtered porewater samples were analyzed immediately or frozen for later analyses. Sulfate concentrations were determined from measurement of conductivity after separation on an IC-Pak anion column by non-suppressed anion exchange chromatography (Waters). Isophthalic acid ( $1 \mathrm{mM})$ in $10 \%$ methanol $(\mathrm{pH} 4.6)$ was used as an eluent. Sulfate concentrations of $<40 \mu \mathrm{M}$ were determined in undiluted porewater samples by suppressed ion chromatography (Sykam, Gilching, Germany).

Methane: Sediment samples were transferred to $60 \mathrm{ml}$ serum vials containing $10 \mathrm{ml}$ of a $2.5 \% \mathrm{NaOH}$ solution. The vials were capped immediately with bromobutyl rubber stoppers and shaken vigorously for 1 min. $\mathrm{NaOH}$ trapped $\mathrm{CO}_{2}$ as $\mathrm{CO}_{3}{ }^{2-}$ whereas $\mathrm{CH}_{4}$ equilibrated with the headspace. Methane gas samples of $0.5 \mathrm{ml}$ from the headspace were analyzed with a gas chromatograph equipped with a flame ionization detector (Packard) after separation on a Poropak Q column. $\mathrm{N}_{2}$ served as carrier gas (flow rate of $20 \mathrm{ml} \mathrm{min}^{-1}$ ). The $\mathrm{CH}_{4}$ peak was recorded on a strip-chart recorder and quantified by comparisons with standards.

Chlorinity: The chloride concentration was measured by colometric titration (CMT 10, Radiometer). Chlorinity was determined in order to reveal whether sulfate depletion with depth was due to fresh water input or not. The chloride concentration (converted to 
salinity) was, together with sediment porosity, also used to calculate the saturation concentration of methane dissolved in the porewater.

Porosity and organic matter: Porosity was determined from density and water content (w/w) and used to recalculate rates from sediment weight to volume. The content of organic matter was determined by loss on ignition $\left(540^{\circ} \mathrm{C}\right.$ for $\left.6 \mathrm{~h}\right)$ of the dried sediment samples.

Rate measurements. Rates of sulfate reduction and methane oxidation were determined for samples from the sediment core and the incubation bags, subsampled into incubation syringes and injected with radioactive ${ }^{35} \mathrm{SO}_{4}{ }^{2-}$ or ${ }^{14} \mathrm{CH}_{4}$, respectively. Gas-tight glass syringes similar to those used by Alperin \& Reeburg (1985) were used to allow headspace-free incubations of 6 to $8 \mathrm{~cm}^{3}$ subsampled sediment. The glass syringe was made at our own workshop from a $12 \mathrm{~mm} / 15 \mathrm{~mm}$ (ID/OD) glass tube, equipped with an O-ring sealed polyoxymethylene piston, and closed by a bromobutyl rubber stopper. Less than 1.5\% methane was lost over $10 \mathrm{~h}$ (corresponding to an incubation period) and was thus of no significance for the measurements.

Sulfate reduction rate measurement: Approximately $200 \mathrm{kBq}$ of carrier free ${ }^{35} \mathrm{SO}_{4}{ }^{2-}(5 \mu \mathrm{ll})$ (Risø, Denmark) was injected into the subsampled sediment. The syringe needle was slowly pulled back through the sediment while the tracer was added from the far end of the incubation syringe. Subsamples from the sediment core were incubated for $8 \mathrm{~h}$ at in situ temperature $\left(15^{\circ} \mathrm{C}\right)$, while subsamples obtained from the incubation bags were incubated for only $4 \mathrm{~h}$ at $22^{\circ} \mathrm{C}$. All incubations were performed in the dark. The incubations were stopped by mixing the sediment with $5 \mathrm{ml}$ of $20 \%$ ZnAc. The preserved sediment was frozen for later analyses.

Reduced sulfur compounds $\left(\mathrm{H}_{2} \mathrm{~S}, \mathrm{FeS}, \mathrm{FeS}_{2}\right.$, and $\left.\mathrm{S}^{0}\right)$ were stripped from the sediment as $\mathrm{H}_{2} \mathrm{~S}$ gas after addition of an acid solution of reduced chromium (i.e. $1 \mathrm{M} \mathrm{Cr}^{2+}$ in $1.5 \% \mathrm{HCl}$ ) or titanium (i.e. $1 \mathrm{M} \mathrm{Ti}^{3+}$ in $10 \% \mathrm{HCl}$ ) to the sediment (Fossing \& Jørgensen 1989 , King 1990). Subsamples from molybdate inhibition experiments were reduced with $\mathrm{Ti}^{3+}$ instead of $\mathrm{Cr}^{2+}$ to overcome the effect of molybdate on the libcration of sulfide (Banat et al. 1981, Oremland \& Capone 1988). A flow of $\mathrm{N}_{2}$ was used to carry the $\mathrm{H}_{2} \mathrm{~S}$ gas from the reaction vessel to test tubes containing $10 \mathrm{ml} 5 \%$ ZnAc. Hydrogen sulfide was trapped as $\mathrm{ZnS}$. A liquid scintillation counter was used to measure (1) the radioactivity of the reduced sulfur compounds in the ZnAc trap and (2) the radioactivity of the non-reduced ${ }^{35} \mathrm{SO}_{4}{ }^{2-}$, separated by centrifugation from the zincpreserved reduced compounds in the sediment. The sulfate reduction rate $\left(\mathrm{nmol} \mathrm{SO} \mathrm{SO}_{4}{ }^{2-}\right.$ reduced $\mathrm{cm}^{-3}$ sedi- ment $\mathrm{d}^{-1}$ ) was then calculated from the fraction of reduced sulfur produced during the incubation and the sulfate concentration in the sample (Fossing \& Jørgensen 1989).

Methane oxidation rates: Approximately $2 \mathrm{kBq}$ of ${ }^{14} \mathrm{CH}_{4}(20 \mu \mathrm{l}, 200 \mathrm{nmol})$ was injected into the incubation syringe using the same technique described for the sulfate reduction rate measurements. Radiolabeled methane was biosynthesized from $\mathrm{H}^{14} \mathrm{CO}_{3}{ }^{-}$ (Amersham Corp.) using the procedure of Daniels \& Zeikus (1983). Subsamples from the sediment core were incubated for $16 \mathrm{~h}$ at in situ temperature, while subsamples from the incubation bags were incubated for $10 \mathrm{~h}$ at $22^{\circ} \mathrm{C}$. During an incubation ${ }^{14} \mathrm{CO}_{2}$ was produced from the injected ${ }^{14} \mathrm{CH}_{4}$ by the methane-oxidizing bacteria. The incubations took place in the dark and were terminated by extruding the sediment into $60 \mathrm{ml}$ serum vials containing $10 \mathrm{ml}$ of a $2.5 \% \mathrm{NaOH}$ solution. ${ }^{14} \mathrm{CH}_{4}$ was sampled from the headspace, injected into a gas chromatograph, combusted, and trapped as ${ }^{14} \mathrm{CO}_{2}$ directly in $8 \mathrm{ml}$ of a $\mathrm{CO}_{2}$ trapping solution [ethanolamine/ethyleneglycolmonomethylether $; 1: 7$ (v/v)]. The activity of ${ }^{14} \mathrm{CO}_{2}$ (present in the sediment as ${ }^{14} \mathrm{CO}_{3}{ }^{2-}$ after preservation in $\mathrm{NaOH}$ ) was analyzed after the ${ }^{14} \mathrm{CH}_{4}$ had been degassed carefully from in the sediment. A volume of $14 \mathrm{ml}$ of $50 \%$ $\mathrm{H}_{3} \mathrm{PO}_{4}$ was added to the sediment and the $\mathrm{CO}_{2}$ gas was stripped in a flow of air directly into $8 \mathrm{ml}$ of the $\mathrm{CO}_{2}$ trap (Iversen \& Blackburn 1981). Scintillation cocktail (10 ml Ultima Gold, Packard) was added to the $\mathrm{CO}_{2}$ trap before counting. The ${ }^{14} \mathrm{CO}_{2}$ recovered was corrected for contamination with ${ }^{14} \mathrm{CO}_{2}$ present in the injected ${ }^{14} \mathrm{CH}_{4}$ tracer.

The methane oxidation rate was calculated from the fraction of ${ }^{14} \mathrm{CO}_{2}$ produced during the incubation, the methane concentration, and the incubation time (Iversen \& Blackburn 1981) and was expressed in nmol $\mathrm{cm}^{-3} \mathrm{~d}^{-1}$. As the methane concentration increased during some of the incubations, an average $\mathrm{CH}_{4}$ concentration was used to determine the methane oxidation rates.

Methane production: The rate of methane production was calculated from the increase in methane concentration over time and corrected for diffusive loss. The diffusive loss was proportional to the total amount of methane in the bag and equalled approximately $0.9 \% \mathrm{~d}^{-1}$

\section{RESULTS}

Sediment from Norsminde Fjord which was sampled at 3 times during summer 1992 had similar density, porosity and chlorinity profiles (data not shown). Density was highest in the 5 to $15 \mathrm{~cm}$ depth horizon at about 
$1.4 \mathrm{~g} \mathrm{~cm}^{-3}$, and decreased to $1.2 \mathrm{~g} \mathrm{~cm}^{-3}$ at $>20 \mathrm{~cm}$ depth. Porosity profiles were inverse in shape. The lowest porosity values were around $0.7 \mathrm{ml} \mathrm{cm} \mathrm{cm}^{-3}$, the

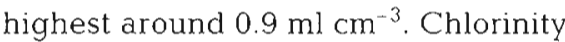
decreased from $320 \mathrm{mM} \mathrm{Cl}^{-}$at the surface to approx. $300 \mathrm{mM} \mathrm{Cl}^{-}$at $>5 \mathrm{~cm}$ depth.

The sediment could be divided into 2 distinct zones, based on organic matter content. Zone 1 extended from the surface down to approximately $19 \mathrm{~cm}$ depth. Here the organic matter content varied between 6 and $9 \%$ of sediment dry weight; below $19 \mathrm{~cm}$, the organic content was significantly higher (15 to $22 \%$ ).

\section{Undisturbed sediment cores}

Concentration profiles of sulfate and methane were negatively correlated. The highest sulfate concentrations were observed at the sediment surface while high methane concentrations, often above saturation $(1200 \mathrm{nmol}$ $\mathrm{cm}^{-3}$ ), were found at the bottom of the cores (Fig. 1a, c). The methane profile was concave, indicating net methane consumption. Sulfate concentrations were around $16 \mu \mathrm{mol} \mathrm{cm} \mathrm{cm}^{-3}$ at the surface and decreased rapidly with depth to $<90 \mathrm{nmol} \mathrm{cm} \mathrm{cm}^{-3}$ (below $27 \mathrm{~cm}$ ). In cores collected on July 24 a local sulfate minimum of $125 \mathrm{nmol} \mathrm{cm}{ }^{-3}$ was observed at 7 or $8 \mathrm{~cm}$ depth (Fig. 1a). It coincided with a local maximum in the methane concentration profile of 140 to $340 \mathrm{nmol} \mathrm{cm}^{-3}$. Consequently, net methane production took place at the depth where the highest sulfate reduction rate was observed (>335 $\mathrm{nmol} \mathrm{cm}^{-3} \mathrm{~d}^{-1}$ ) (Fig. 1b). The me-

thane oxidation rate increased with depth to $15 \mathrm{nmol}$ $\mathrm{cm}^{-3} \mathrm{~d}^{-1}$ at $37 \mathrm{~cm}$ depth. From 31 to $37 \mathrm{~cm}$ depth, the rate of methane oxidation exceeded the rate of sulfate reduction 2- to 8-fold (Fig. 1b insert). On August 2, a second maximum in the sulfate reduction rate (118 $\mathrm{nmol} \mathrm{cm}^{-3} \mathrm{~d}^{-1}$ ) was observed close to the depth where also the highest methane oxidation rate of $17 \mathrm{nmol} \mathrm{cm} \mathrm{cm}^{-3} \mathrm{~d}^{-1}$ was determined (Fig. 1d). However, at this depth methane oxidation could account for $14 \%$ of the sulfate reduced. These observations imply that the sediment was not in steady state with respect to sulfate
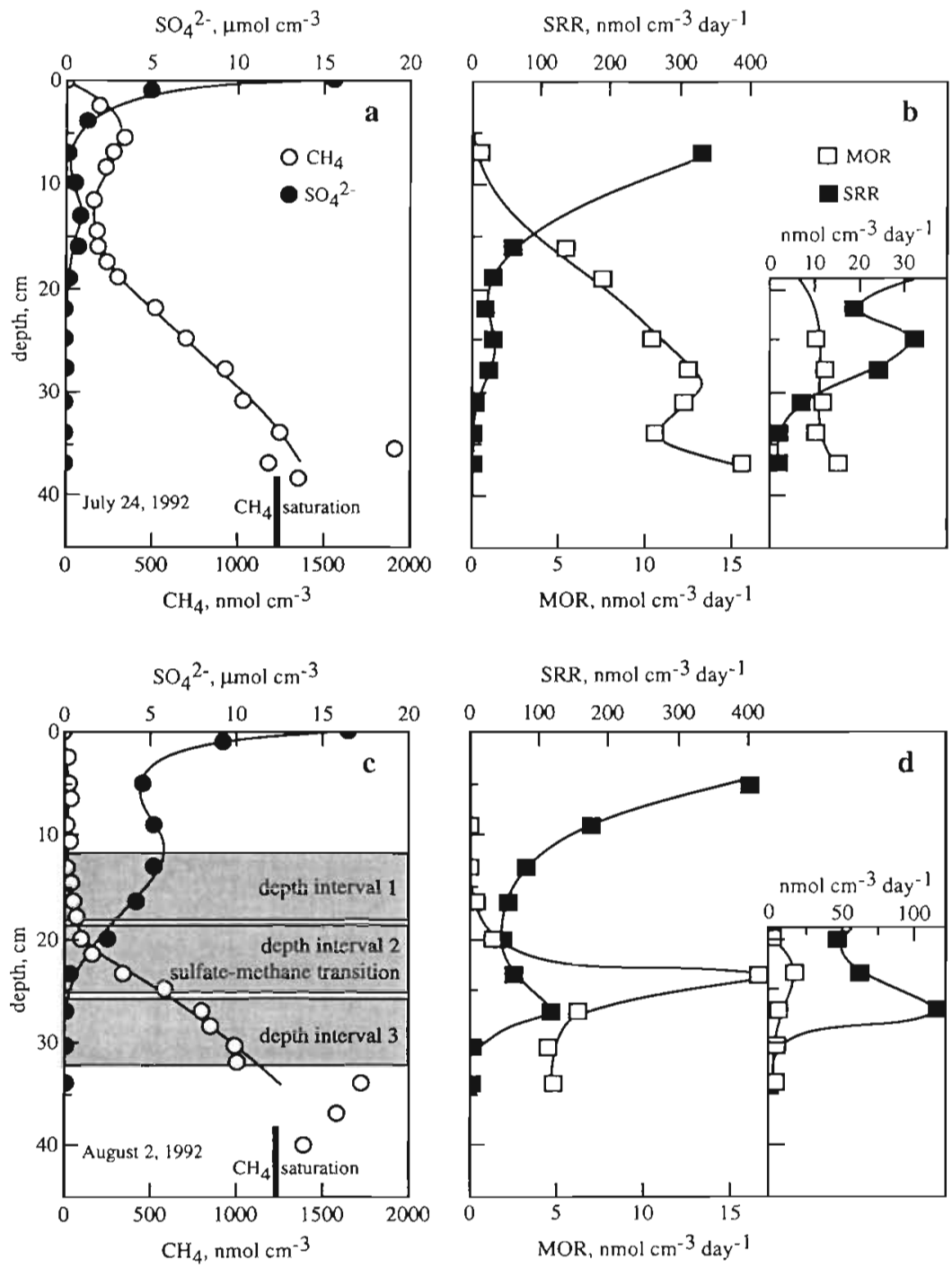

Fig. 1. Concentration and rate measurements in undisturbed sediment cores from Norsminde Fjord measured on (a, b) July 24 and (c, d) August 2, 1992. (a, c) Concentrations of methane and sulfate are expressed on different scales. Methane saturation is shown by a vertical bar on the methane concentration (c) (see text). (b, d) Rate measurements of methane oxidation (MOR) and sulfate reduction (SRR) are shown on different scales. Inserts show rates for $18 \mathrm{~cm}$ and deeper, and are expressed on the same scale

and methane during the time between the 2 sampling campaigns.

\section{Bag incubations}

The bag incubation experiments revealed almost identical results for equally treated bags from the 3 sediment horizons. Thus, only results from the time course experiments made with sediment from the sulfatemethane transition zone sediment are presented (Fig. 2). 

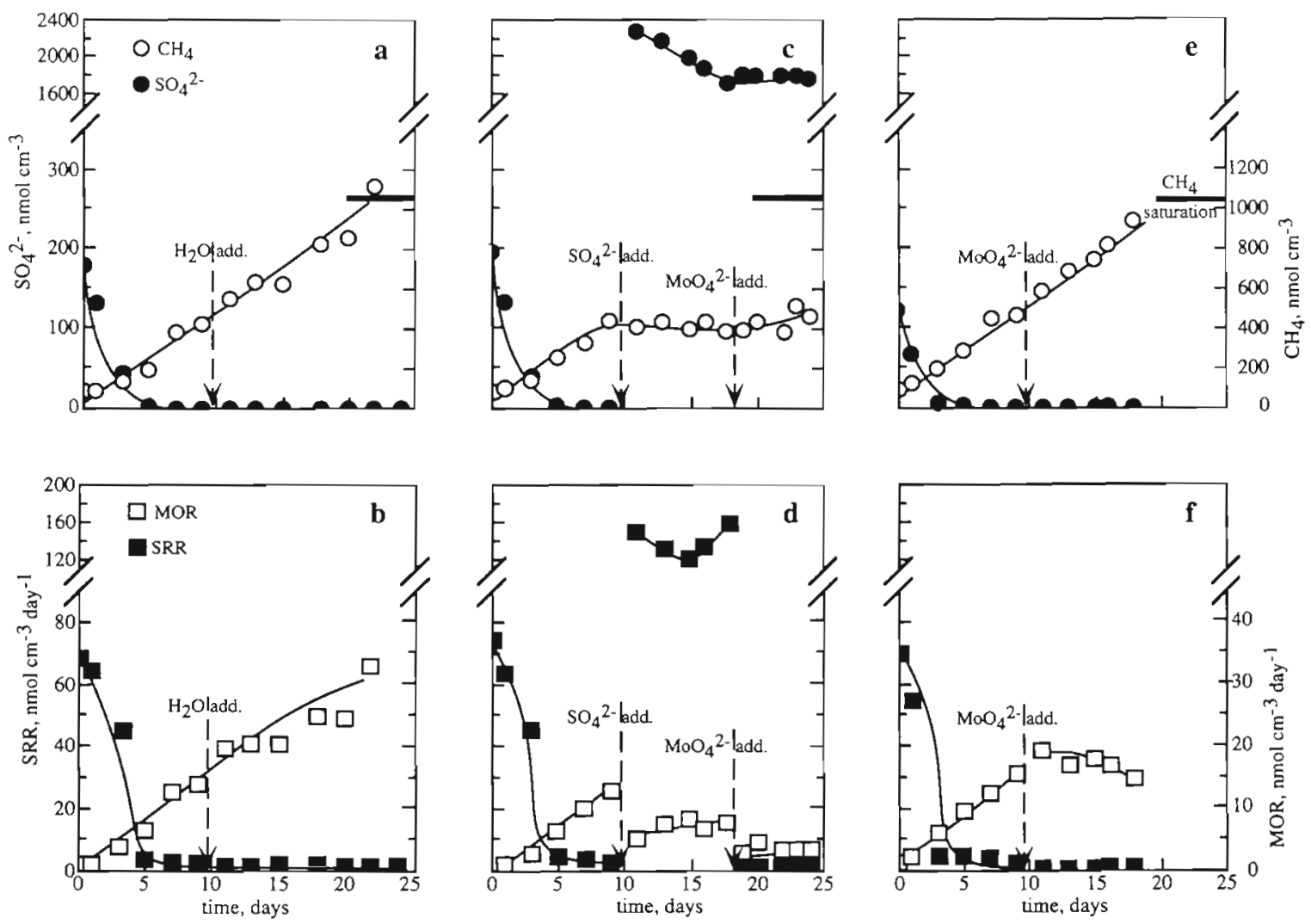

Fig. 2. Bag incubation experiments with sediment from the sulfate-methane transition zone (depth interval 2). (a, $c_{1}$ e) Time course of sulfate and methane concentrations over $25 \mathrm{~d}$ in 3 incubation bags. Methane saturation is shown by a horizontal bar on the methane concentration scale. (b, $d, f)$ Respective rates of methane oxidation (MOR) and sulfate reduction (SRR) measured by radio labelling with ${ }^{14} \mathrm{CH}_{4}$ and ${ }^{35} \mathrm{SO}_{4}{ }^{2-}$, respectively. $(\mathrm{a}, \mathrm{b})$ Control experiment. Arrow shows addition of anoxic Milli- $\mathrm{Q}$ water. $(c, d)$ Sulfate-amended experiment. Arrows show addition of sulfate and molybdate, respectively. (e, f) Molybdate inhibition experiments. Arrow shows addition of molybdate

\section{Control experiment (Fig. 2a, b)}

Initially, the concentrations and rates measured in the control experiment followed those measured in the other 2 incubation experiments. However, after water, sulfate, or molybdate were added to the 3 bags, only the control experiment was unaffected by the manipulation (i.e. addition of anoxic Milli-Q water), whereas rates and concentrations changed in the other 2 bags. After $25 \mathrm{~d}$ of incubation when the methane concentration had reached saturation, the methane oxidation rate exceeded the sulfate reduction rate by more than 20 -fold $\left(33 \mathrm{nmol} \quad \mathrm{CH}_{4} \quad \mathrm{~cm}^{-3}\right.$ $\mathrm{d}^{-1}: 1.4 \mathrm{nmol} \mathrm{SO}_{4}{ }^{2-} \mathrm{cm}^{-3} \mathrm{~d}^{-1}$ ).

\section{Sulfate-amended experiment (Fig. 2c, d)}

Sulfate reduction rates increased from less than 2 to more than $120 \mathrm{nmol} \mathrm{cm} \mathrm{cm}^{-3} \mathrm{~d}^{-1}$ when sulfate was added to sulfate-depleted sediment (ca 1 to $2.5 \mu \mathrm{mol} \mathrm{cm}^{-3}$ final concentration). Net methane production ceased instantaneously, and the methane oxidation rate decreased from 13 to $5 \mathrm{nmol} \mathrm{cm} \mathrm{cm}^{-3} \mathrm{~d}^{-1}$. When molybdate was added after $18 \mathrm{~d}$ of incubation, sulfate reduction was immediately inhibited. Net methane production, however, was stimulated, whereas methane oxidation rates decreased slightly.

Molybdate inhibition experiment (Fig. 2e, f)

The addition of molybdate did not affect net methane production when compared to the control experiment. However, molybdate uncoupled the rate of methane oxidation from the methane concentration. This effect was not immediate, and first became obvious $3 \mathrm{~d}$ after the $\mathrm{MoO}_{4}{ }^{2-}$ addition. Then, methane oxidation decreased from 20 to $15 \mathrm{nmol} \mathrm{cm}^{-3} \mathrm{~d}^{-1}$ at the end of the experiment. 
Turnover rate of ${ }^{14} \mathrm{CH}_{4}$ tracer

The methane oxidation rate (MOR) was positively correlated to methane concentration $\left(\left[\mathrm{CH}_{4}\right]\right)$ in $\mathrm{MoO}_{4}{ }^{2-}$ - and $\mathrm{SO}_{4}{ }^{2-}$-free sediment as observed from a rapid increase of the $\mathrm{MOR} /\left[\mathrm{CH}_{4}\right]$ ratio to a constant level of $3.1 \% \mathrm{~d}^{-1}$ (Fig. 3). The constant $\mathrm{MOR} /\left[\mathrm{CH}_{4}\right]$ ratio obtained with bags containing sediment from depth interval 1 was about $40 \%$ lower than the ratio found in bags with sediment from depth intervals 2 and 3. When sulfate or molybdate was added to sediment from the sulfate-methane transition zone, the $\mathrm{MOR} /\left[\mathrm{CH}_{4}\right]$ ratio decreased by $59 \%$ to $1.3 \% \mathrm{~d}^{-1}$ $2 \mathrm{~d}$ after sulfate addition, and by $47 \%$ to $1.6 \% \mathrm{~d}^{-1}$ 9 d after molybdate addition, respectively. The MOR/ $\left[\mathrm{CH}_{4}\right]$ ratio was further reduced to $0.6 \% \mathrm{~d}^{-1}$ (i.e. a $80 \%$ reduction in total) when molybdate was added $9 \mathrm{~d}$ after the sulfate addition. A similar response was observed in incubations bags filled with sediment from depth intervals 1 and 3 . Thus, the effect of sulfate and molybdate was apparently additive.

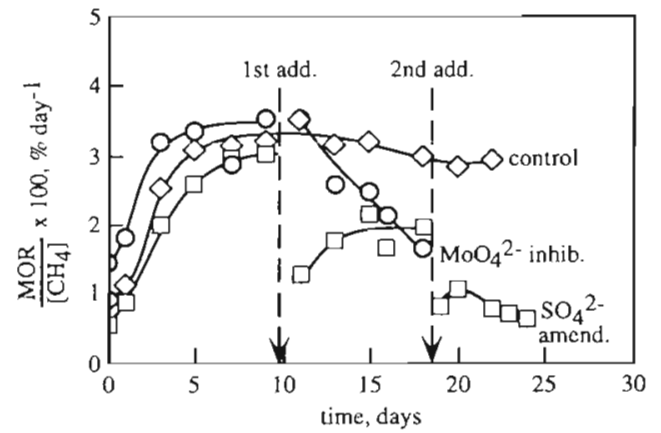

Fig. 3. Correlation between methane oxidation rates (MOR) and methane concentrations during a time course of $25 \mathrm{~d}$. Obtained from bag incubations with methane-sulfate transition zone sediments (see Fig. 2c). First arrow (1st add.): addition of anoxic Milli- $\mathrm{Q}$ water, $\mathrm{SO}_{4}{ }^{2-}$, and $\mathrm{MoO}_{4}{ }^{2-}$ to respectively the control experiment, the sulfate-amended experiment, and the molybdate experiment. Second arrow (2nd add.): addition of molybdate to the sulfate-amended experiment. For a detailed explanation of the 3 types of experiment please see the text
Table 1. Methane oxidation rates (MOR), gross methane production rates (Gross MPR) and the ratios of methane oxidation rates versus methane concentration (MOR/[CH 4$]$ and methane oxidation rates versus gross methane production rates (MOR/Gross MPR) are given for the unamended control bags from depth intervals (zones) 1,2, and 3 (for detailed description of the depth intervals see 'Material and methods' section). $n$ : number of replicates used.

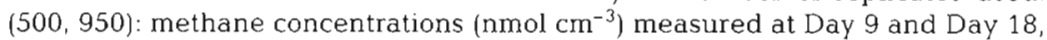
respectively. Values given in bold were corrected for methane production due to glove bag hydrogen $\left(40 \mathrm{nmol} \mathrm{CH} \mathrm{Cm}^{-3} \mathrm{~d}^{-1}\right.$ )

\begin{tabular}{|c|c|c|c|c|c|c|c|}
\hline \multirow[t]{2}{*}{ Zone } & \multirow[t]{2}{*}{$\begin{array}{l}\mathrm{MOR} /\left[\mathrm{CH}_{4}\right] \\
\left(\mathrm{d}^{-1}\right)\end{array}$} & \multicolumn{2}{|c|}{$\begin{array}{c}\text { MOR } \\
\left(\mathrm{nmol} \mathrm{cm} \mathrm{cm}^{-3} \mathrm{~d}^{-1}\right)\end{array}$} & \multicolumn{2}{|c|}{$\begin{array}{c}\text { Gross MPR } \\
\left.\text { (nmol cm-3 } \mathrm{d}^{-1}\right)\end{array}$} & \multicolumn{2}{|c|}{$\begin{array}{c}\text { MOR/ } \\
\text { Gross MPR (\%) }\end{array}$} \\
\hline & & $(500)$ & $(950)$ & $(500)$ & $(950)$ & $(500)$ & $(950)$ \\
\hline 1 & $0.19 \pm 0.01(6)$ & 10 & 18 & $52(12)$ & $65(25)$ & $19(83)$ & $28(72)$ \\
\hline 2 & $0.31 \pm 0.02(9)$ & 16 & 30 & $67(27)$ & $86(36)$ & $24(60)$ & $35(\mathbf{6 5 )}$ \\
\hline 3 & $0.35 \pm 0.05(7)$ & 17 & 33 & $68(28)$ & 89 (39) & $25(61)$ & $37(67)$ \\
\hline
\end{tabular}

Table 2. Methane oxidation rates (MOR), gross methane production rates (Gross MPR) and the ratio of methane oxidation rates and gross methane production rates (MOR/Gross MPR) before and after addition of sulfate or molybdate are given for incubations with sediment from depth interval 2 (sulfatemethane transition zone). Gross MPR was calculated in 2 different ways: (1) assuming constant methane concentration (Fig. 2C) between Days 9 and 18, number outside parenthesis; and $\cdot(2)$ using linear regression on methane con centrations (Fig. 2C) from Days 9 to 18 , number within parenthesis

\begin{tabular}{|c|c|c|c|c|}
\hline & \multicolumn{2}{|c|}{$\mathrm{MoO}_{4}^{2-}$} & \multicolumn{2}{|c|}{$\mathrm{SO}_{4}^{2-}$} \\
\hline & $\begin{array}{l}\text { Before } \\
\text { (Day } 9 \text { ) }\end{array}$ & $\begin{array}{c}\text { After } \\
\text { (Day 18) }\end{array}$ & $\begin{array}{l}\text { Before } \\
\text { (Day 9) }\end{array}$ & $\begin{array}{l}\text { After } \\
\text { (Day 18) }\end{array}$ \\
\hline $\operatorname{MOR}\left(\mathrm{nmol} \mathrm{cm}^{-3} \mathrm{~d}^{-1}\right)$ & 16 & 16 & 13 & 7.6 \\
\hline Gross MPR (nmol cm $\mathrm{cm}^{-3} \mathrm{~d}^{-1}$ ) & 68 & 72 & 65 & $11(7.3)^{\circ}$ \\
\hline MOR/Gross MPR (\%) & 24 & 22 & 20 & $67(104)^{\circ}$ \\
\hline
\end{tabular}

Methane oxidation rate towards gross methane production

The gross methane production rate (gross MPR) was compared to the MOR by calculating the ratio of MOR/gross MPR in the control experiments (Table 1). The MOR/gross MPR ratio increased during the experiments, indicating that methane oxidation is stimulated more than methane production with time. The ratio (\%) was lower in bags containing sediment from depth interval 1 (19 to $28 \%$ ) than in bags with sediment from depth intervals 2 (24 to $35 \%$ ) and 3 (25 to $37 \%$ ). The addition of sulfate increased the MOR/gross MPR ratio to about $67 \%$, while the ratio decreased to approximately $22 \%$ after molybdate addition (Table 2).

\section{DISCUSSION}

Our observations on sulfate reduction and anaerobic methane oxidation in undisturbed sediment cores and during bag incubations are discussed in light of the prevailing hypotheses on the coupling between these processes. Common for these hypotheses 

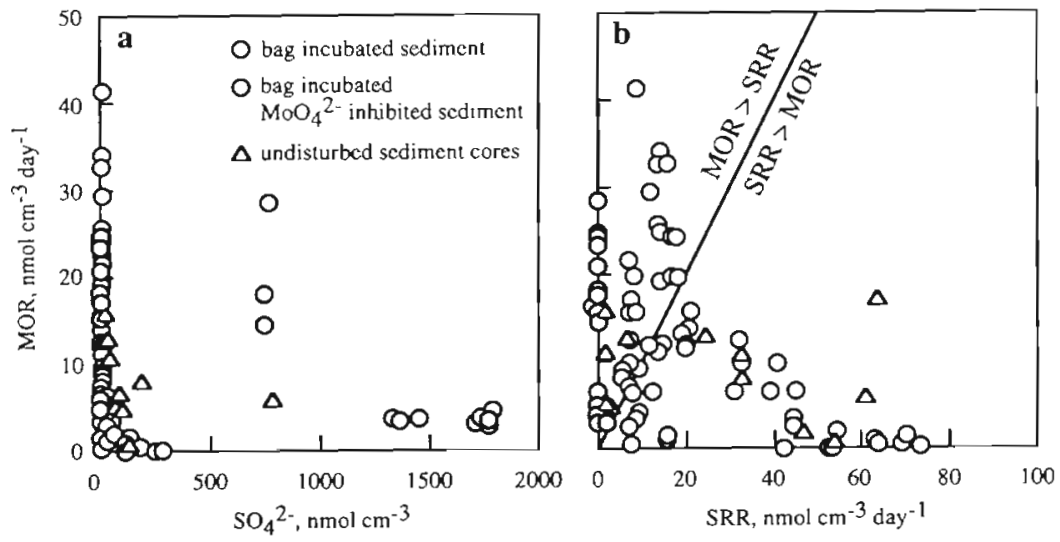

Fig. 4. Correlation between methane oxidation rates (MOR) and (a) sulfate concentrations and (b) sulfate reduction rates (SRR\}. Obtained during bag incubations with sediment from 3 different sediment intervals, 1,2 and 3 , respectively (see Fig. 1c). Also enclosed are observations from Norsminde Fjord undisturbed sediment cores measured on July 24 and August 2, 1992, respectively (see Fig. 1) Note that $\left[\mathrm{SO}_{4}{ }^{2-}\right]>2000 \mu \mathrm{mol} \mathrm{cm}{ }^{-3}$ is not shown in (a), however, for these sulfate concentrations MOR $<1 \mathrm{nmol} \mathrm{cm}{ }^{-3} \mathrm{~d}^{-1}$. Omitted values only relate to observations from the undisturbed sediment cores. The solid line in (b) indicates equal rates of methane oxidation and sulfate reduction. Note that SRR $>100 \mathrm{nmol} \mathrm{cm}{ }^{-2}$ $\mathrm{d}^{-1}$ observed in the undisturbed sediment cores are not shown

\section{Methane oxidation in intact cores}

Methane oxidation was observed in undisturbed sediment cores both at high and at low sulfate concentrations (Fig. 1). The methane oxidation rates were pronounced at the sulfatemethane transition zone in the August 2 samples, and appeared together with a local sulfate reduction rate maximum (Fig. 1d). At this depth, however, 10 to $30 \%$ of the sulfate reduction could be explained by methane oxidation alone. These values are lower than Iversen \& Jørgensen (1985) reported for Kattegat sediments where methane oxidation was equivalent to about $60 \%$ of the sulfate-mediated carbon mineralization.

The hypothesis that sulfate reducers alone oxidize methane becomes very doubtful when the methane zone sampled during July 24 is examined. At sediment depths below $30 \mathrm{~cm}$, the

is that (1) methane oxidation is biologically mediated and (2) that sulfate-reducing bacteria are involved. Therefore, the most interesting question to discuss is whether our data support either the hypothesis that anaerobic methane oxidation is mediated by only 1 metabolic type (a sulfate-reducing bacteria) or the hypothesis that methane is oxidized by a consortium of 2 or more bacteria species as suggested by Zehnder $\&$ Brock (1980) and Hoehler et al. (1994). We designed our experiments to study the role sulfate reducers play in the oxidation of methane. Accordingly, we expected that methane oxidation would be highly affected by the presence or absence of sulfate. However, both in intact sediment cores and during bag incubations, we observed methane oxidation also at sulfate concentrations below the detection limit of our method, $<2$ to $5 \mu \mathrm{M}$ (Fig. 4a). These observations agree with the findings of Panganiban et al. (1979), Zehnder \& Brock (1980) and Hoehler et al. (1994) and led us to conclude that methane metabolism is not dependent on bacteria that actively reduce sulfate. This conclusion was supported by the fact that molybdate completely inhibited sulfate reduction (Fig, 4b), but only uncoupled methane oxidation rates from methane concentrations (Fig. 3). Thus, the 'single organism hypothesis' is seriously questioned by our observations. In contrast, our results support the 'consortium hypothesis', which assumes that methane is oxidized by methanogenic bacteria in association with other bacteria (Zehnder \& Brock 1980, Hoehler et al. 1994). methane oxidation rate exceeded the sulfate reduction rate 2 to 8 times (Fig. 1b insert). Similar observations of methane oxidation rates exceeding sulfate reduction rates have also been made in Cape Lookout Bight sediments (Hoehler et al. 1994). Thus methane oxidation, at least at these depth and locations, must be carried out by organisms other than sulfate reducers.

\section{Methane oxidation in incubation bags}

Effect of glove bag hydrogen on methane production

Methane production in the incubation bags was probably influenced by hydrogen diffusing into the bags from the glove bag atmosphere $\left(5 \% \mathrm{H}_{2}\right)$. Based on product information (J. W. Hansen) and own measurements, we estimated a 'bag diffusion coeffient' for $\mathrm{H}_{2}$ of approximately 8 times the coeffient determined for methane. The glove bag hydrogen could thus support an influx of $50 \mu \mathrm{mol} \mathrm{H} \mathrm{H}_{2} \mathrm{~d}^{-1}$ which could result in a methane production rate of $40 \mathrm{nmol} \mathrm{cm} \mathrm{cm}^{-3} \mathrm{~d}^{-1}$, given a $300 \mathrm{ml}$ mud volume and assuming that all hydrogen is converted into methane. Subsampling from the incubation bags decreased the mud volume and consequently increased the relative contribution of glove bag hydrogen to methane production. The final mud volume was about $100 \mathrm{ml}$, resulting in a 3 -fold increase in methane production (120 nmol $\mathrm{CH}_{4} \mathrm{Cm}^{-3} \mathrm{~d}^{-1}$ ). This would result in an exponential increase in methane concentration throughout the incubation period, most 
rapidly towards its end. This prediction is in conflict with the linear shape of the concentration profile observed in all incubations. Hence, this discrepancy may be due to the fact that methanogenesis has reached its maximum rate $\left(V_{\max }\right)$. The external supply of hydrogen may be responsible for methanogenesis dominating methane oxidation as expressed by the MOR/gross MPR ratio (Table 1). Therefore, in a hydrogen-free environment, methane production rates may be lower and net methane oxidation may be observed. However, the possible stimulation of methanogenesis by glove bag hydrogen does not influence our general conclusions, even though it may have influenced process regulation in the bag sediments.

\section{Effect of molybdate and sulfate on methane oxidation}

Molybdate inhibited sulfate reduction completely and affected methane oxidation by uncoupling the rate of methane oxidation from its concentration. It may influence growth of the methane-oxidizing community or inhibit enzyme synthesis. In both cases, $\mathrm{MoO}_{4}{ }^{2-}$ would uncouple methane consumption from methane concentration and consequently the $\mathrm{MOR} /\left[\mathrm{CH}_{4}\right]$ ratio would decrease (Fig. 3). The fact that molybdate only uncoupled the methane oxidation rate from methane concentrations but did not decrease the oxidation rate immediately (see Fig. 2f) speaks in favour of an inhibition of transcription or translation of the functional enzyme. The minor decrease observed in methane oxidation rate over time after molybdate addition may be explained as a slow degradation of the enzymes involved.

In contrast to the molybdate-amended bags, sulfate addition resulted in an immediate decrease in both methane oxidation and production rates (Fig. 2c, d). A total inhibition of methanogenesis should have resulted in a concentration decrease over time because of methane consumption due to the ongoing methane oxidation and diffusive loss through the plastic membrane of the incubation bag. However, the ongoing methanogenesis may be explained by hydrogen diffusing into the bag from the glove bag atmosphere. The continuous supply of hydrogen may either deplete the sulfate pool locally and thus stimulate methanogenesis or build up $\mathrm{H}_{2}$ concentrations high enough to support both sulfate reduction and methanogenesis.

\section{Conclusion}

Our results support the hypothesis that methanogenic bacteria are responsible for anaerobic methane oxidation, and that sulfate reducers are only indirectly involved as members of a consortium in sulfatedepleted sediments. However, in sulfate-rich sediments, our results indicate that sulfate reducers might be involved in anaerobic methane oxidalion directiy, especially since molybdate immediately, though incompletely, inhibits methane oxidation. In sulfate-containing anoxic environments, net methane oxidation occurs because methanogenesis is competitively inhibited by sulfate reducers. In these environments, methane-oxidizing methanogens may even benefit thermodynamically from sulfate reducers scavenging hydrogen produced together with carbon dioxide during 'reverse methanogenesis'. Thermodynamic calculations indicate that the methane oxidation becomes exergonic at $\mathrm{H}_{2}$ concentrations found in sulfate-containing environments (Hoehler et al. 1994). We will however stress the role of methanogens as the real methane oxidizers, which in both sulfate-poor and sulfate-rich sediments are able to convert methane to $\mathrm{CO}_{2}$ independently from other bacteria.

Acknowledgements. We acknowledge the help of Prof. Bo Barker Jorgensen for having given the inspiration to this investigation. We thank 2 anonymous reviewers for constructive criticism of the manuscript. Kai Finster was financially supported by the Danish Committee on Biotechnology.

\section{LITERATURE CITED}

Aeckersberg F, Bak F, Widdel F (1991) Anaerobic oxidation of saturated hydrocarbons to $\mathrm{CO}_{2}$ by a new type of sulfatereducing bacterium. Arch Microbiol 165 5-14

Alperin MJ, Reeburg WS (1985) Inhibition experiments on the anaerobic methane oxidation. Appl Environ Microbiol 50: 940-945

Banat IM, Lindström EB, Nedwell DB, Balba MT (1981) Evidence for coexistence of two distinct functional groups of sulfate-reducing bacteria in salt marsh sediment. Appl Environ Microbiol 42:985-992

Blair NE, Aller RC (1995) Anaerobic methane oxidation on the Amazon shelf. Geochim Cosmochim Acta 59:3707-3715

Daniels L, Zeikus JG (1983) Convenient biological preparation of pure high specific activity ${ }^{14} \mathrm{C}$-labeled methane. $J$ Labelled Compd Radiopharm 20:17-24

Davis JB, Yarborough HE (1966) Anaerobic oxidation of hydrocarbons by Desulfovibrio desulfuricans. Chem Geol $1: 137-144$

Devol AH (1983) Methane oxidation rates in the anaerobic sediments of Saanich Inlet. Limnol Oceanogr 28:738-742

Devol AH, Anderson JJ, Kuivila K, Murray JW (1984) A model for the coupled sulfate reduction and methane oxidation in the sediments of Saanich Inlet. Geochim Cosmochim Acta 48:993-1004

Fossing H, Jorgensen BB (1989) Measurements of bacterial sulfate reduction in sediments: evaluation of single-step chromium reduction method. Biogeochemistry 9:205-222

Hansen JW (1992) Den økologiske betydning af mangan i marine sedimenter herunder oxidation af reducrede svovlforbindelser. MSc thesis, University of Aarhus

Harder J (1997) Anaerobic methane oxidation by bacteria employing ${ }^{14} \mathrm{C}$-methane uncontaminated with ${ }^{19} \mathrm{C}$-carbon monoxide. Mar Geol 137:13-23 
Hoehler TM, Alperin MJ, Albert DB, Martens CS (1994) Field and laboratory studies of methane oxidation in an anoxic marine sediment: evidence for a methanogen-sulfate reducer consortium. Global Biogeochem Cycles 8: $451-463$

Iversen $N$ (1984) Interaktioner mellem fermenteringsprocesser og de terminale processer. PhD thesis, University of Aarhus

Iversen N, Blackburn TH (1981) Seasonal rates of methane oxidation in anoxic marine sediments. Appl Environ Microbiol 41:1295-1300

Iversen N, Jørgensen BB (1985) Anaerobic methane oxidation rates at the sulfate-methane transition in marine sediments from Kattegat and Skagerrak (Denmark). Limnol Oceanogr 30:944-955

King GM (1990) Effects of added manganic and ferric oxides on sulfate reduction and sulfide oxidation in intertidal sediments. FEMS Microbiol Ecol 73:131-138

Kruse B (1993) Measurement of plankton $\mathrm{O}_{2}$-respiration in gas-tight plastic bags. Mar Ecol Prog Ser 94:155-163

Martens CS, Berner RA (1977) Interstitial water chemistry of Long Island Sound. I. Dissolved gases. Limnol Oceanogr 22:10-25

Oremland RS, Capone DC (1988) Use of 'specific' inhibitors in biogeochemistry and microbial ecology. In: Marshall $\mathrm{KC}$

Editorial responsibility: Tom Fenchel,

Helsinger, Denmark (ed) Advances in microbial ecology. Plenum Press, London, p 285-383

Panganiban AT, Patt TE, Hart W, Hanson RS (1979) Oxidation of methane in the absence of oxygen in lake water samples. A.ppl Environ Microbiol 37:303-309

Popp BN, Sansona FJ, Rust TM (1995) Determination of concentration and carbon isotopic composition of dissolved methane in sediments and nearshore waters. Analyt Chem 67:405-411

Postgate JR (1969) Methane as a minor product of pyruvate metabolism by sulfate-reducing and other bacteria. J Gen Microbiol 57:293-302

Reeburgh WS (1976) Methane consumption in Cariaco Trench waters and sediments. Earth Planet Sci Lett 28:337-349

Reeburgh WS (1980) Anaerobic methane oxidation: rate depth distributions in Skan Bay sediments. Earth Planet Sci Lett 47:345-352

Sorokin Y'I (1957) Ability of sulfate reducing bacteria to utilize methane for reduction of sulfate to hydrogen sulfide. Dokl Akad Nauk SSSR Ser Biol 115:816-818

Zehnder BJ, Brock TD (1979) Methane formation and methane oxidation by methanogenic bacteria. J Bacteriol $137: 420-432$

Zehnder BJ, Brock TD (1980) Anaerobic methane oxidation: occurrence and ecology. Appl Environ Microbiol 39:194-204

Submitted: April 8, 1997; Accepted: August 18, 1997

Proofs received from author(s): November 14, 1997 